\title{
Primary pulmonary lymphoma
}

\author{
J. Cadranel*,\#, M. Wislez*,\#, M. Antoine ${ }^{\#, \bullet}$
}

\begin{abstract}
Primary pulmonary lymphoma. J. Cadranel, M. Wislez, M. Antoine. (C) ERS Journals Ltd 2002.

ABSTRACT: Three distinct entities are now covered by the definition of primary pulmonary clonal lymphoid proliferation. The aim of this review is to describe the pathophysiological, diagnostic, prognostic and therapeutic aspects of these three entities.

Low-grade pulmonary B-cell lymphoma is the most frequent form of primary pulmonary clonal lymphoid proliferation. It arises from mucosa-associated lymphoid tissue. It is usually indolent and appears in the form of a chronic alveolar opacity. The prognosis is excellent, but treatment is controversial (simple monitoring, surgery or single-agent chemotherapy). High-grade pulmonary B-cell lymphoma is far rarer and usually occurs in individuals with an underlying disorder (e.g. immunodeficiency). The prognosis is poor and therapeutic options depend on the underlying disorder.

The inclusion of lymphomatoid granulomatosis in the definition of primary pulmonary lymphomas is controversial. The clonal nature of the proliferation is very rarely demonstrated and extrapulmonary involvement is frequent (upper airways, skin, kidneys, central nervous system, etc.). The prognosis is extremely variable, with some authors reporting complete remission with steroids and cyclophosphamide and others reporting failure of combination chemotherapy.

Eur Respir J 2002; 20: 750-762.
\end{abstract}

*Dept of Pneumology and Respiratory Intensive Care, and " Dept of Pathology, Tenon Hospital, and Laboratory of Cell Biology and Immunopathology of the Lung (UPRES EA 3493), University of Paris VI, Paris, France.

Correspondence: J. Cadranel, Service de Pneumologie et de Réanimation Respiratoire, Hôpital Tenon, 4 rue de la Chine, Paris 75020 France.

Fax: 33156016968

E-mail: jacques.cadranel@tnn.ap-hopparis.fr

Keywords: Chronic alveolar opacity lymphomatoid granulomatosis mucosa-associated lymphoid tissue primary pulmonary lymphoma

Received: April 222002 Accepted: April 222002
Lymphomatous proliferation can involve the lungs in three ways: 1) by haematogenous dissemination of non-Hodgkin's lymphoma (NHL) or Hodgkin's disease (HD); 2) by contiguous invasion from a hilar or mediastinal site of nodal lymphoma; and 3) by primary pulmonary involvement. The first two situations involve progression or relapse of a known lymphomatous disorder, and treatment focuses on the haematological disorder. The third situation, the focus of this review, poses a number of diagnostic and therapeutic problems for pneumologists.

Primary pulmonary lymphoma (PPL) is defined as clonal lymphoid proliferation affecting one or both lungs (parenchyma and/or bronchi) in a patient with no detectable extrapulmonary involvement at diagnosis or during the subsequent 3 months $[1,2]$. When the lung is the principal tumour site, this definition also includes: 1) multifocal mucosa-associated lymphoid tissue (MALT) NHL; 2) pulmonary involvement with satellite nodes (hilar or mediastinal); and 3) multiorgan involvement by lymphomatoid granulomatosis, the clonal nature of which is controversial.

PPL is very rare. While extranodal forms represent $24-50 \%$ of cases of NHL [1-3], PPL represent only $3-4 \%$ of extranodal NHL, $<1 \%$ of NHL, and only $0.5-1 \%$ of primary pulmonary malignancies $[1,4,5]$. The current definition of PPL $[1,6]$ covers: 1) lowgrade B-cell PPL (PPL-B), the most frequent form; 2) high-grade PPL-B; and 3) lymphomatoid granulomatosis (LG), a rare disorder.

\section{Primary pulmonary B-cell non-Hodgkin's lymphoma: MALT non-Hodgkin's lymphoma}

\section{Evolution of concepts and terminology}

Low-grade PPL-B corresponds to what was formerly called "pseudolymphoma". The term pseudolymphoma

Previous articles in this series: No. 1: Steels E, Paesmans M, Berghmans T, et al. Role of p53 as a prognostic factor for survival in lung cancer: a systematic review of the literature with a meta-analysis. Eur Respir J 2001; 18: 705-719. No. 2: van Klaveren RJ, Habbema JDF, Pedersen JH, de Koning HJ, Oudkerk M, Hoogsteden HC. Lung cancer screening by low-dose spiral computed tomography. Eur Respir J 2001; 18: 857-866. No. 3: Brambilla E, Travis WD, Colby TV, Corrin B, Shimosato Y. The new World Health Organization classification of lung tumours. Eur Respir J 2001; 18: 1059-1068. No. 4: Brock CS, Lee SM. Anti-angiogenic strategies and vascular targeting in the treatment of lung cancer. Eur Respir J 2002; 19: 557-570. No. 5: Hirsch FR, Merrick DT, Franklin WA. Role of biomarkers for early detection of lung cancer and chemoprevention. Eur Respir J 2002; 19: 1151-1158. No. 6: Field JK, Youngson JH. The Liverpool Lung Project: a molecular epidemiological study of early lung cancer detection. Eur Respir J 2002; 20: 464479. 
was chosen because of doubts over the malignant nature of these slowly progressive lesions and their relatively benign histological aspect [7-10]. Routine use of sensitive immunohistochemical techniques [5, 11-17] and molecular biology-based methods [17] in fact showed that most pseudolymphomas contained clonal proliferation, thus demonstrating their lymphomatous nature. The term pseudolymphoma was therefore abandoned and these lymphomas were subdivided as follows: lymphocytic, diffuse with small lymphocytes, mixed diffuse, or diffuse with small cleaved cells, in the Working Formulation; lymphocytic, lymphoplasmocytic, centrocytic, centroblastic/centrocytic diffuse in the Kiel classification [5, 11-17]; and MALT lymphoma in the Revised European-American Classification of Lymphoid Neoplasms (REAL) classification [18]. In the latest classification (World Health Organization (WHO) classification) [19], MALT lymphomas belong to the marginal zone lymphomas but are distinguished from nodal and splenic forms by their different clinical behaviour and cytogenetic characteristics [19-22]. However, some cases of low-grade PPL-B do not correspond to the definition of MALT-type NHL and high-grade PPL-B has also been described [1].

\section{Mucosa-associated lymphoid tissue lymphoma}

Bronchial mucosa-associated lymphoid tissue. MALT is a lymphoid tissue specialising in mucosal defence [1]. It was first described in the gastrointestinal tract of animal models, then in the human ileum. It comprises of Peyer's patches, a lamina propria, intra-epithelial lymphocytes and mesenteric lymph nodes. Peyer's patches are lymphoid nodules with an architecture similar to that of lymph node follicles, except that the marginal B zone is more highly developed in the former. The lamina propria contains immunoglobulin (Ig) A-secreting plasmocytes and $\mathrm{T}$ lymphocytes. Phenotypically, intra-epithelial lymphocytes are CD8+ T-cells. The stomach is the most frequent site of MALT lymphoma and serves as a model for pulmonary MALT lymphoma. As in the stomach, MALT is absent from the lung in physiological circumstances. During chronic antigenic stimulation (by Helicobacter pylori, for example), MALT can develop in the stomach and undergo secondary lymphomatous transformation arising from marginal zone B-cells. In order to develop, the malignant B-cell clone requires the presence of $\mathrm{T}$-cells specifically directed against $H$. pylori antigens. Thus, $H$. pylori eradication can lead to lengthy complete remission of gastric lymphoma [23]. No triggering antigens have so far been identified in the lung, but chronic antigenic stimulation in certain autoimmune disorders (systemic lupus erythematosus, multiple sclerosis, Hashimoto's thyroiditis and particularly Gougerot-Sjögren's syndrome) are considered to affect the onset of pulmonary MALT lymphoma [23].

Epidemiology. Low-grade NHL-B accounts for 58$87 \%$ of cases of PPL in pathological series $[5,12$,
15, 17]. Nearly $90 \%$ of these cases correspond to MALT-type NHL [12, 15, 17]. Age of onset is $\sim 50-60$ yrs $(12-79$ yrs) and subjects $<30$ yrs are rarely affected $[5,9,11,13,14,16,24]$. The two sexes are equally affected $[5,9,11,13,14,16,24]$.

Clinical and radiological signs. Nearly half these patients are asymptomatic at diagnosis and are identified fortuitously on the basis of a radiological pulmonary anomaly $[5,11,13,14,24]$. When present, symptoms, such as cough, mild dyspnoea, chest pain and occasionally haemoptysis, are nonspecific [5, 9, 11, 13, 14, 16, 24]. Pulmonary auscultation reveals crackles in $<20 \%$ of cases [24]. By definition, extrapulmonary manifestations are restricted to general signs (fever and weight loss) and occur in less than one quarter of patients $[5,11,13,14,24]$. The usual radiological aspect $(50-90 \%$ of cases) is a localised alveolar opacity, with a diameter of $<5 \mathrm{~cm}$ and blurred or well-defined contours (according to the series); it is associated in nearly $50 \%$ of cases with an air bronchogram (fig. 1a) [13, 14, 24]. Computed tomography (CT) (figs. 1b and c), which is more sensitive than standard radiography, has demonstrated that the lesions are usually bilateral $(60-70 \%)$ and multiple $(70-77 \%)[25,26]$. Nearly all these lesions contain clear areas corresponding to an intact bronchial lumen (fig. 2). The presence of distended bronchi within the lesions is a good diagnostic sign, although the underlying mechanism is unexplained [26]. Less than $10 \%$ of patients have bilateral diffuse reticulonodular opacities, atelectasia or pleural effusion [13, 14, 24]. CT can reveal hilar and mediastinal adenopathies $[9,24]$. The interval between the first clinical or radiological manifestations and diagnosis ranges from 5 months to 8 yrs [5, 11, 13, 14, 24].

Contribution of bronchial endoscopy. Bronchial endoscopy usually shows a normal macroscopic aspect [24], although abnormalities ranging from mucosal inflammation to bronchial stenosis can be observed [24]. The diagnostic yield of bronchial, and especially transbronchial, biopsy is higher when it targets visible endobronchial lesions or radiographic abnormalities [24]. However, the absence of specific signs in most of these samples necessitates further diagnostic investigations $[5,9,11,13,14,16,24]$. Bronchoalveolar lavage (BAL) is very useful for differential diagnosis of chronic alveolar opacities [27]. In contrast, its value for the positive diagnosis of PPL is inadequately assessed. BAL has proven useful in isolated cases of PPL [28-38], while its use is not always mentioned in large published series [5, 9, 11, 13, $14,16]$. BAL appears to be particularly valuable if it shows lymphocytic alveolitis (lymphocytes $>20 \%$ of total cells), which is found in about two-thirds of these patients [24, 27, 29, 31]. This lymphocytosis, which is usually composed principally of T-cells, is only a specific sign when $>10 \%$ of $\mathrm{B}$ lymphocytes are present [24, 29, 32]. B-cell alveolitis is particularly valuable when its clonal nature can be demonstrated by the detection of Ig gene clonal rearrangements using molecular biology-based methods (Southern blot 

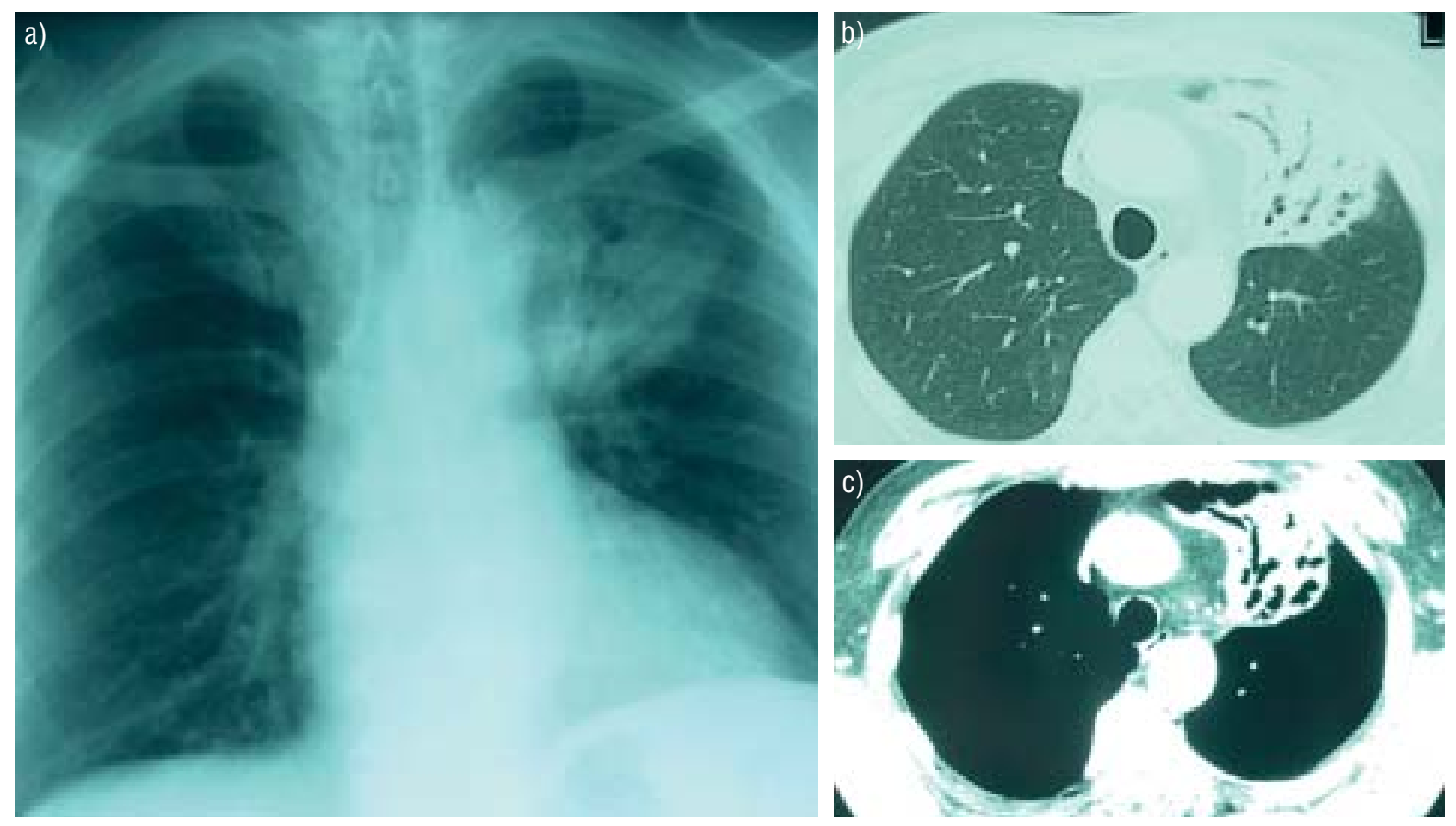

Fig. 1.-Pulmonary mucosa-associated lymphoid tissue (MALT) lymphoma. a) Standard face-on radiography showing a mass in the upper left lobe containing an air bronchogram. Computed tomography sections (b) parenchymatous and c) mediastinal window) showing the upper left lobe containing an air bronchogram.

or reverse transcriptase-polymerase chain reaction) [35-37, 39, 40]. However, these methods are not widely used in routine practice and require further evaluation of their sensitivity and specificity. They can already be used to diagnose a recurrence of histologically proven PPL. Screening for monoclonal Ig in the BAL supernatant by immunoelectrophoresis $[24,33,38,41]$ and restricted membranous or intracytoplasmic Ig light-chain expression by slide immunohistochemistry or flow cytometry [29-32, 38] have been used but have been replaced by molecular biology-based methods.

Diagnostic criteria. The diagnosis of MALT-type NHL is based on histological examination of surgical samples or bronchial, transbronchial or transthoracic biopsy material.

Results of conventional histology. The macroscopic aspect is that of a whitish, soft and poorly-defined mass. Microscopically, MALT-type PPL is defined as a lesion [11, 13, 15, 17, 42] containing: 1) proliferation of small lymphoid cells analogous to the marginal zone cells of Peyer's patches or spleen follicles, centrocyte-like cells and small lymphocytes, plasmocytes or monocytoid cells; 2) a lymphoepithelial lesion showing lymphoid cell migration from the marginal zone to the bronchiolar epithelium; 3) reactive follicular hyperplasia; and 4) rare blastic cells. More unusual features include amyloid deposits $[10,43]$ and granulomatous deposits [10, 12, 43]. Various degrees of fibrosis can be found. Lymphomatous infiltration causes smooth or nodular interstitial thickening with a peribronchovascular distribution [12] (fig. 3).

Contribution of immunohistochemistry. Immunohistochemical analysis contributes to the differential and positive diagnosis of MALT-type PPL. It shows the B-cell phenotype (CD19, CD20) [5, 11-17] and clonal nature $[15,17]$ of the lymphoid infiltrate invading follicular structures and invading the bronchial/bronchiolar epithelium (fig. 3). It also reveals, by the persistence of dendritic cells (CD21, CD35), the presence, within the tumoural proliferation, of destroyed follicles, together, in most cases, with small reactive $\mathrm{T}$ lymphocytes (CD3) in the alveolar wall infiltrate and around peribronchiolar nodules [12, 17]. Above all, immunohistochemical tests can rule out low-grade lymphoma (centrofollicular NHL-B, mantel NHL-B and chronic lymphocytic leukaemia (CLL)-type lymphoma) by showing the lack of CD5 and CD10 surface antigens [12, 17, 44, 45].

Contribution of molecular biology. Southern blotting is performed on frozen samples. Using an Ig heavychain gene target sequence $(\mathrm{Fr} 3 / \mathrm{JH})$, the monoclonal nature of the proliferation was shown in 12 out of 20 samples of MALT-type PPL [17].

Differential diagnosis. Differential diagnosis of MALTtype PPL is based on clinical and histological grounds. Clinically, the problem boils down to diagnosing MALT-type PPL after radiological identification of a chronic localised or diffuse alveolar or 


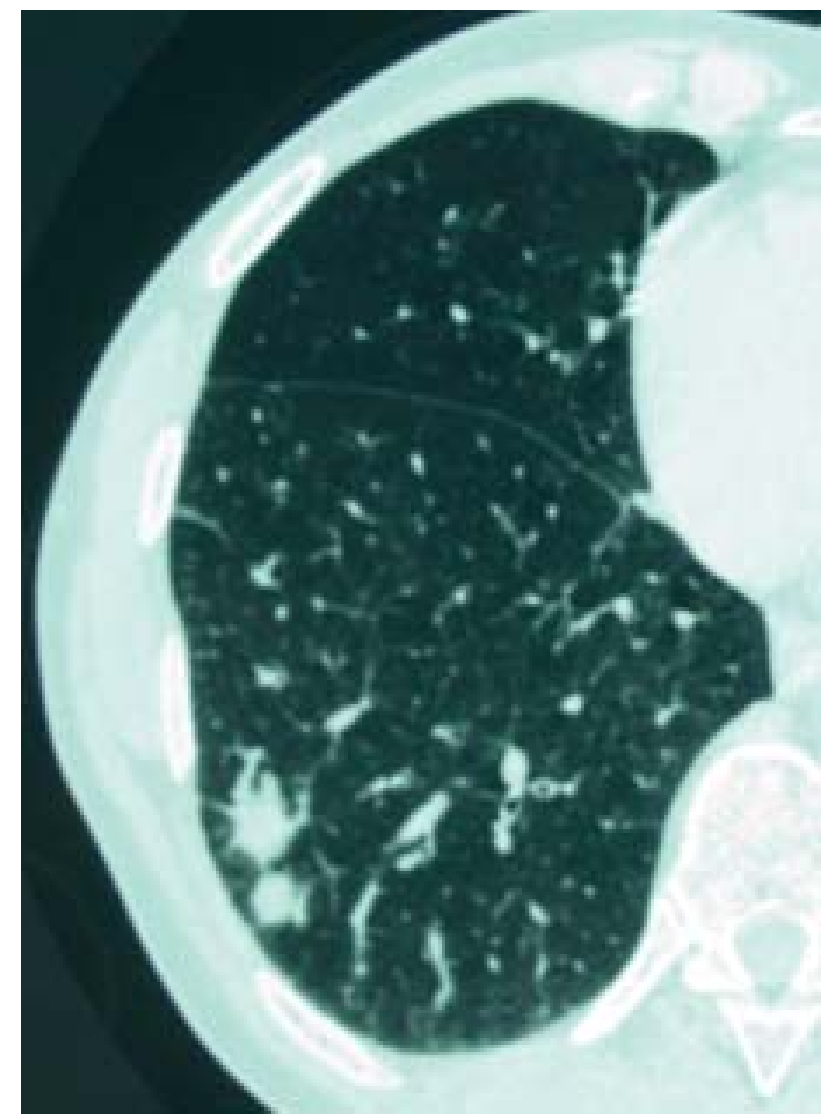

Fig. 2.-Pulmonary mucosa-associated lymphoid tissue (MALT) lymphoma. Computed tomography section (parenchymatous window) showing two joined peripheral nodules with blurred contours located in the lower right lobe. One of the nodules is bronchocentric.

interstitial opacity, which can have a wide range of aetiologies (table 1).

Histologically, especially when the sample is small, the main difficulty is distinguishing MALT-type NHL from diffuse lymphoid hyperplasia or interstitial lymphoid pneumonia (ILP), and follicular bronchitis (FB). This distinction may seem irrelevant to the clinician, because the radiological and clinical features of these disorders often differ from those of MALTtype PPL [47]. Other histological entities, such as extrinsic allergic alveolitis, can be considered, owing to their similar radiological expression and the presence of a lymphoid lesion. Some other nodular pulmonary lesions also have a lymphoid contingent, such as plasmocyte granuloma, inflammatory pseudotumours, fibrous histiocytoma, pulmonary hyalinising granuloma, intrapulmonary adenopathies, and Castleman's disease [48].

Pretreatment extension work-up. Nodal lymphoma is ruled out by abdominal and thoracic CT with contrast enhancement. Although bone marrow involvement is far more frequent in lymphoma of the nodal or splenic marginal zone [21], bone marrow biopsy is crucial, showing signs of invasion in $\leqslant 20-30 \%$ of patients in recent series of MALT lymphoma [49, 50]. Similarly, these series showed concomitant involvement of other mucosal lymphoid sites in $25-35 \%$ of cases [47-51], and even more frequently in patients with MALT lymphoma not involving the gastrointestinal tract. The search for other mucosal sites must include ophthalmological and ear, nose and throat (ENT) examinations (with magnetic resonance imaging (MRI) or CT of the salivary and lacrimal glands in suspect cases), plus upper gastrointestinal endoscopy (and coloscopy plus small-intestinal transit, according to some authors). The only useful laboratory tests in the pretreatment work-up are serum electrophoresis and immunoelectrophoresis. Monoclonal gammopathy (IgM in eight out of 10 cases) is found in $20-60 \%$ of cases, especially in forms with plasmocyte differentiation $[5,9,14,24]$. A recent study showed that an elevated $\beta 2$ microglobulin level is an independent predictor of poor survival [50].

Course, prognosis and treatment. Course and prognostic factors. The outcome of MALT-type PPL is generally favourable in most series, with a 5-yr survival rate of $>80 \%$ and a median survival time of $>10$ yrs [5, 9-11, 13, 15, 24]. The overall survival of these patients is longer than that of patients with lymphoma of the nodal or splenic marginal zone [21]. In contrast, it has not yet been demonstrated that the survival of patients with MALT-type PPL is equivalent to that of the general population $[10,52]$. The median survival of patients with gastrointestinal MALT-type PPL does not differ from that of patients with other localisations, but progression-free survival appears to be shorter in the latter, especially in patients with pulmonary forms [53]. Long-term surveillance is necessary, owing to the frequency of late local or extrathoracic relapse after surgical resection (almost $50 \%$ of patients after $>2 \mathrm{yrs})[5,10,11,16,24]$. No clear prognostic factors have been identified in MALT lymphoma. In univariate analysis, some all-comer series of MALT lymphoma have shown a pejorative influence of age over $60 \mathrm{yrs}$, elevated $\beta_{2}$ microglobulin and failure to enter a complete response during firstline treatment [50]. The only prognosticator in multivariate analysis is elevated $\beta_{2}$ microglobulin. According to other authors, intratumoural amyloid deposition is a factor of poor prognosis, while lymphoepithelial lesions are associated with a good prognosis [52]. A recent series of 48 patients with PPL identified no prognostic factors among the following: presentation, bilaterality, tumour/nodes/ metastasis (TNM) stage, surgical resection, adjuvant chemotherapy and several histological criteria [54].

Some authors have suggested that low-grade PPL can transform into high-grade proliferation, based on the existence of mixed forms or transitional forms identified by serial biopsy [5, 9, 12, 15, 17]. This conflicts with recent studies showing differences between the cytogenetic abnormalities of low-grade and high-grade PPL. For example, the $t(11 ; 18)$ translocation is only present in low-grade PPL [55]. For this reason, the latest revision of the WHO classification recommends the use of the term "large B-cell lymphoma" rather than "high-grade MALT lymphoma" [19]. 

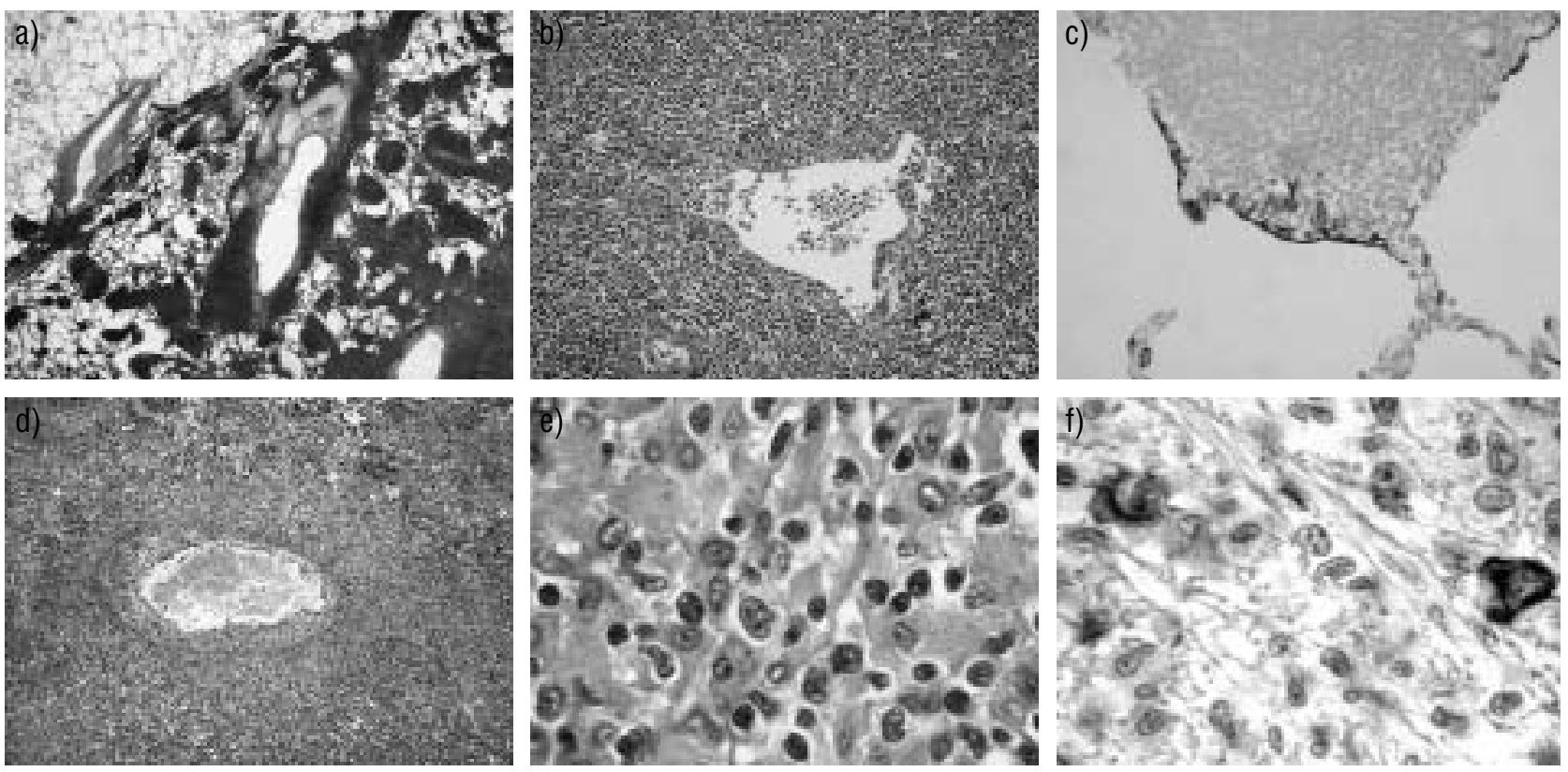

Fig. 3. - Pulmonary mucosa-associated lymphoid tissue (MALT) lymphoma (a-c). a) Interstitial proliferation with peribronchovascular tropism (HES $\times 25$ ). b) Lymphoepithelial lesion, with the bronchiolar epithelium masked or partially destroyed by the lymphoid infiltrate $($ HES $\times 200)$. c) Residual epithelial cells are revealed with an anticytokeratin antibody (immunohistochemistry, avidin-biotin peroxidase $\times 100$ ). Pulmonary lymphomatoid granulomatosis $(\mathrm{d}-\mathrm{f})$. d) Lymphoid proliferation with vascular parietal invasion $($ HES $\times 100)$. e) Mixed cell population with large atypical lymphoid cells and small lymphoid cells $(\mathrm{HES} \times 1000)$. f) Large atypical lymphoid cells are revealed with an anti-CD20 antibody (immunohistochemistry, avidin-biotin peroxidase $\times 1000$ ).

Principles of treatment. There is no consensus on treatment. The lack of an identified culprit antigen in the lung, contrary to the stomach ( $H$. pylori), means that antibiotics effective on low-grade localised gastric lymphoma are inappropriate. Current treatment options are surgery, chemotherapy and radiotherapy [5, 9-11, 14-16]. The respective efficacy of these treatments cannot be analysed, however,

Table 1.-Principal aetiologies of chronic solitary or multiple alveolar opacities

\author{
Frequent causes \\ Viral or bacterial pneumonia, slowly resolving ${ }^{\#}$ \\ Organising pneumonia (BOOP) \\ Tuberculosis \\ Pulmonary infarction \\ Pulmonary contusion \\ Localised pulmonary oedema \\ Less frequent causes \\ Bronchioloalveolar cancer ${ }^{\#}$ \\ Pseudo-alveolar sarcoidosis ${ }^{\#}$ \\ Pulmonary hypersensitivity ${ }^{\#}$ \\ Lymphoma\# \\ Alveolar proteinosis ${ }^{\#}$ \\ Oily pneumonia ${ }^{\#}$ \\ Radio-induced pneumonitis ${ }^{\#}$ \\ Eosinophilic pneumonia \\ Alveolar haemorrhage \\ Atypical Pneumocystis carinii pneumonia \\ Opportunistic bacterial pneumonia (nocardiosis, \\ actinomycosis, etc.)
}

BOOP: bronchiolitis obliterans with organising pneumonia. \#: the most frequent tentative diagnoses (owing to their clinically subacute presentation) [46]. owing to a lack of comparative series, and some authors even propose simple clinical monitoring [11]. Nevertheless, surgical resection is commonly preferred for localised tumours [5, 9-11, 14-16]. Exclusive chemotherapy is generally used for patients with bilateral or extrapulmonary involvement, relapse or progression. Combination regimens, such as cyclophosphamide, adriamycin, oncovin and prednisone (CHOP), have not proven more effective than single-agent regimens with chloraminophene, cyclophosphamide, azathioprine or steroids [9, 11, 14]. Radiotherapy is rarely used [5, 9, 11, 14, 15].

\section{Other forms of B-cell primary pulmonary lymphoma}

Low-grade B-cell primary pulmonary lymphoma. In $<10 \%$ of cases, low-grade PPL-B does not meet the histological criteria of MALT-type NHL. According to the WHO classification [18], these cases can correspond to follicular or mantel lymphocytic NHL or CLL. The clinical and pulmonary radiological aspects are similar to those of MALT-type PPL $[12,15]$.

High-grade primary pulmonary lymphoma-B. Highgrade NHL-B represents $11-19 \%$ of cases of PPL in published series $[12,15,17]$; MALT-type NHL coexists in $\sim 50 \%$ of cases. High-grade NHL-B often occurs in patients with underlying disorders, such as solid organ (heart/lung) transplantation with cyclosporine $\mathrm{A}$ or OKT3 immunosuppression [56-60], human immunodeficiency virus (HIV) infection [60-63] and GougerotSjögren's syndrome [64]. It is reminiscent of high-grade pleural NHL in acquired immune deficiency syndrome 
(AIDS) patients $[60,65]$ and in patients with pleural sequelae of collapsotherapy. Epstein-Barr virus (EBV) has been implicated in the onset of some of these highgrade NHL affecting the lung [62, 63, 65-68].

Excluding HIV-infected subjects, mean age at onset is $\sim 60$ yrs $(30-80$ yrs $)[5,9,10,15,24]$. Patients are usually symptomatic, with respiratory manifestations, fever or weight loss [5, 9, 10, 15, 24]. Radiological investigations usually show a single pulmonary mass or atelectasia. Pleural effusion is also often present $[5,9,10,15,24]$. In the current authors' experience, multiple and/or excavated opacities are frequently found in HIV-infected patients [61-63]. Bronchial endoscopy is often abnormal, with budding or infiltrative stenosis with a tumoural aspect [5, 9, 24]. The histological diagnosis is generally easy, even with very small samples (bronchial, transbronchial or transthoracic biopsy), owing to the presence of blast-like lymphoid cells with strong mitotic activity, clearly indicative of malignancy [5, 9, 24, 69]. The lymphoid infiltrate aggresses the bronchial, vascular (endoluminal invasion) or pleural structures, and necrosis is usually found. Most cases are immunoblastic and centroblastic NHL [5, 9, 12, 15, 17, 24]. Histology has a limited role in differential diagnosis [48]. The highly atypical cytological aspect means that immunohistochemistry is required to rule out carcinoma, melanoma or sarcoma if there is a marked fibroblastic reaction, and especially extension of a nodal lymphoma or leukemic involvement. Markedly angiotropic lesions raise the possibility of lymphomatoid granulomatosis

Survival is poorer in high-grade PPL than in lowgrade PPL. Overall, the median survival time is $\sim 8-10$ yrs $[5,9,24]$, but it is far lower in patients with underlying disorders (HIV infection, transplantation, collapsotherapy). Progression and local or distant relapse occur earlier and are more frequently $[5,9,24]$. Treatment after surgical resection is often based on the combination chemotherapy regimens used for high-grade nodal NHL [5, 9, 24].

Primary pulmonary plasmocytoma. Primary pulmonary plasmocytoma is extremely rare. Less than 50 cases have been reported in the literature [70, 71]. Age at onset is $\sim 40$ yrs, although cases have been described in children and older patients [70,71]. The two sexes are equally affected. Patients are usually asymptomatic, but fever, weight loss, chest pain, dyspnoea, cough and even haemoptysis have occasionally been described [70, 71]. The most common radiological aspect is that of an isolated pulmonary nodule, but a case of bilateral diffuse lung disease has been reported [72]. A hilar adenopathy is observed in $<10 \%$ of cases [70]. Bronchial endoscopy is always normal and the diagnosis is almost always based on thoracotomy findings [70]. Histologically, the lesions are composed solely of plasmocytes with variable degrees of cytological anomalies [70, 71]. Amyloid lesions can be present [73]. By definition, immunohistochemical studies show monoclonal intracytoplasmic immunoglobulin expression [70, 71, 73]. This differentiates these cases from low-grade lymphoma, which always contains small lymphocytes and reactive plasmocytes expressing polyclonal $\mathrm{Ig}[70,71,73]$.

In patients with suspected primary pulmonary plasmocytoma, myeloma must be ruled out by normal bone marrow and skeletal examination [70]. Treatment is mainly based on surgical excision of the plasmocytoma. If surgery is contraindicated, most plasmocytomas are radiosensitive. The overall 2- and 5 -yr survivals of primary pulmonary plasmocytoma are $66 \%$ and $40 \%$, respectively [71]. Despite complete tumour excision, $15-30 \%$ of patients develop multiple myeloma within a few years [70].

Pulmonary intravascular lymphoma. Pulmonary intravascular lymphoma is due to proliferation of atypical lymphoid cells within the lumen of capillaries, arterioles, venules and lymph ducts, with little or no invasion of the adjacent parenchyma. It is usually located in the central nervous system and skin. The underlying mechanism appears to be the loss of certain surface receptors on lymphoid cells, preventing their extravascular migration. Pulmonary involvement is rare [74, 75], with about 15 cases reported in the literature. Usually, the clinical and radiological picture is that of diffuse interstitial lung disease with hypoxemia and fever [75, 76]. There is no mediastinal node involvement. There is frequently an altered general state and a lactate dehydrogenase elevation [77], and cerebral, renal or cutaneous involvement is almost always present $[74,75]$. A case of pulmonary arterial hypertension [76] and a case of respiratory insufficiency with air trapping [77] have been reported. Transbronchial biopsies can assist with the diagnosis [77], as can cytological analysis of pulmonary capillary blood cells [78]. Combination chemotherapy regimens used in high-grade NHL have some efficacy, giving a complete response rate of $\sim 50 \%$.

\section{Lymphomatoid granulomatosis: immunoproliferative angiocentric pulmonary legions}

\section{Evolution of concepts and terminology}

Lymphomatoid granulomatosis (LG) was initially described within the framework of pulmonary angiitis and granulomatosis. It was first recognised as a clinical and anatomical entity distinct from Wegener's granulomatosis (and probably linked to EBV) by LiEBOW and co-workers in 1972 [79, 80]. Patients generally have an altered general state, with pulmonary nodules and extrathoracic involvement (usually cutaneous and neurological) [79, 80]. The histological lesion is an "atypical, angiocentric, angiodestructive and granulomatous lymphoreticular infiltrate" [79, 80]. Several questions have been raised since this initial description:

Is lymphomatoid granulomatosis a lymphoid malignancy? Clinically, LG is characterised by the absence of node, hepatosplenic or bone marrow involvement evocative of NHL. Its natural course is extremely variable. Spontaneous remissions have been reported $[34,81,82]$ and prolonged complete remissions have 
been obtained in nearly $50 \%$ of patients with steroids and cyclophosphamide [83, 84]. However, in most published series the prognosis is grim, with death occurring in $>50 \%$ of cases, despite combination chemotherapy $[34,79,81,84,85]$. Histologically, the lesions sometimes have a lymphomatous aspect, with areas of large atypical lymphoid cells. Authentic highgrade NHL is diagnosed during the course of the disease or at autopsy in from $10 \%$ to nearly $50 \%$ of patients. Immunohistochemical and molecular biology-based analyses performed in two series showed evidence of clonality in five out of 11 and six out of nine cases of LG $[86,87]$. Given this variable clinical course and lesional aspect, some authors grade the lesions from 1 (minimal anomalies) to 3 (maximal anomalies), based on the proportions of atypical and inflammatory cells [81, 85, 88, 89]. A recent study showed a correlation between lesional grade and the B-cell proliferation index, but not the T-cell, macrophage or natural killer-cell proliferation index. The proliferation index of grade-3 lesions appears to be identical to that of large B-cell NHL [90].

Is lymphomatoid granulomatosis a lymphoid lesion of the $T$ or $B$ phenotype? The definition of $\mathrm{LG}$ as an immunoproliferative T-cell disorder is now being challenged. The T-lymphomatous nature of some cases of LG had been suggested on the basis of an aberrant T-cell phenotype or a chromosomal abnormality, but clonal rearrangement of $\mathrm{T}$-cell receptor genes has never been demonstrated [83, 87, 91-94]. Other studies based on immunohistochemistry and molecular biology showed, in fact, that most LG correspond to the definition of B-cell NHL. In these studies, the large atypical cells expressed B-cell markers (CD20) and showed restricted Ig light-chain expression (K or L) $[87,91,92,95,96]$. Molecular biology studies usually show clonal rearrangement of $\operatorname{Ig}$ genes $[86,87$, 91, 96].

Is lymphomatoid granulomatosis induced by EpsteinBarr virus? A large number of studies point to a role of EBV in the pathogenesis of LG, as in post-transplant and HIV-related lymphoproliferative syndromes [86, $87,97,98]$. Viral proteins (lysosome-associated membrane protein (LMP) and EBV-associated nuclear antigen (EBNA)) or viral genomic sequences (EBR1 and EBR2) have been found within the lymphoid infiltrate in $59-72 \%$ of cases of LG studied so far [86, 87, 97, 98]. A recent study showed that EBV-infected tumour cells bear B-cell markers [98]. Viral proteins (LMP1 and EBNA2) normally induce a cytotoxic Tcell response, which appears to be deficient in LG [98].

\section{Lymphomatoid granulomatosis}

Epidemiology. LG is rare. Between 500-600 cases have been reported in the literature, in the form of case reports and series of $10-150$ patients $[34,79,82,84,85$, $88,99-101]$. Age at onset is $\sim 30-50$ yrs (2.5-85 yrs) [34, $79,80,84,85,88,99-101]$. Males seem to be more susceptible than females, with a sex ratio of between 1-6.5 males per female [34, 79, 82, 84, 85, 88, 99-101].
No geographical or ethnic susceptibility factors have been found.

Clinical and radiological pulmonary signs. Nearly $90 \%$ of patients are symptomatic at diagnosis and present with a 4- to 8-month history of general and respiratory symptoms [34, 79, 82, 84, 85, 88, 99-101]. Respiratory symptoms are found in $54 \%$ to $>80 \%$ of cases, and mainly consist of cough and dyspnoea. Chest pain and potentially life-threatening haemoptysis can occur [79, $82,99]$. Fever, weight loss or sweating occur in $30-70 \%$ of cases. Cases of acute respiratory distress have been reported. In one series, the average oxygen tension in arterial blood was $8.9 \mathrm{kPa}(67 \mathrm{mmHg}$ (40$100 \mathrm{mmHg})$ ) and there was a restrictive, obstructive or mixed syndrome in $40 \%, 20 \%$ and $15 \%$ of cases, respectively [34].

The radiological aspect in $>80 \%$ of cases is that of multiple poorly-defined nodular opacities measuring $1-8 \mathrm{~cm}$ in diameter. They are bilateral and predominate in the lower lobes $[34,79,81,82,84,85,88,99$, 102-104]. The nodules have a peribronchovascular distribution and tend to converge to form pseudotumoural masses and excavate, and can disappear or migrate spontaneously ("wax and wane") [82, 88, 103] (fig. 4). Anatomical-radiological correlation studies have shown that excavated masses correspond to infarcted granulomatosis lesions [104, 105]. Unilateral or single nodules, alveolar opacities, and bilateral reticulonodular involvement are more unusual. Mild pleurisy is observed in $40 \%$ of cases $[34,79,82,85,99$, $102,106]$ and pneumothorax has only been described in patients with excavated nodules [82]. Hilar adenopathies are found in $25 \%$ of cases $[81,82,102]$.

Extrapulmonary manifestations. Extrapulmonary manifestations mainly affect the skin, nervous system or ENT sphere. They can precede, coincide with or follow the onset of respiratory manifestations [34, $79,81,82,84,85,88,99]$. Cutaneous involvement is observed in $36-53 \%$ of cases, and consists of erythema, nodules and, more rarely, mucosal ulceration [85].

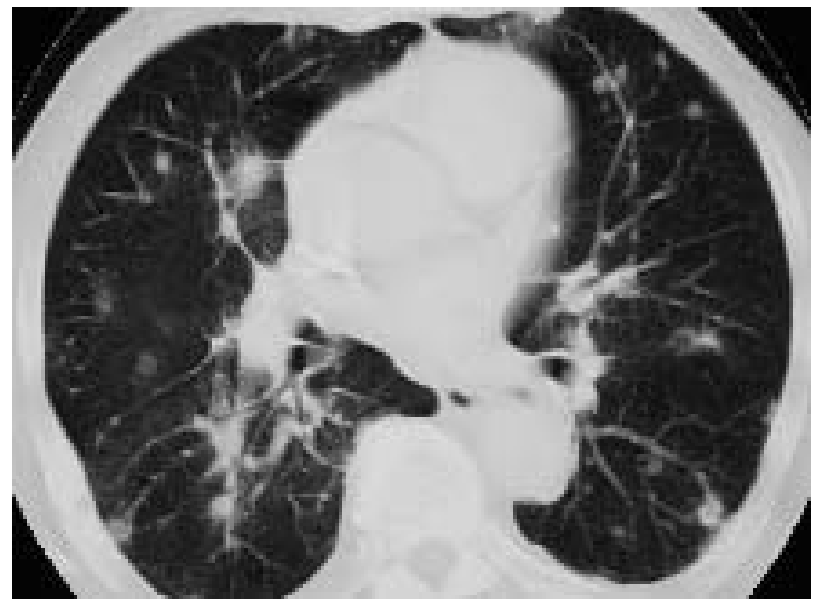

Fig. 4.-Pulmonary lymphomatoid granulomatosis. Computed tomography section (parenchymatous window) showing multiple nodules with peribronchovascular distribution predominating in the lower lobes. 
Neurological involvement takes the form of central deficits (blindness, hemiparesis, ataxia, convulsions, coma, headache, confusions, etc.), sensory-motor neuropathies affecting the limbs or cranial nerves, and, far more rarely, hypothalamic-pituitary involvement, and occurs in $10-35 \%$ of cases $[34,79,81,82$, $84,85,88,99]$. Ulceration of the upper airways is described in $10-30 \%$ of cases $[34,81,84,85]$. The frequency of renal involvement is variously reported; it is $\sim 0-10 \%$ at diagnosis and increases during the course of the disease, reaching $30-40 \%$ in some autopsy series [79, $81,84]$. It is almost always due to a mass syndrome; creatinemia and the urinary sediment are usually normal. Specific peripheral adenopathies are also infrequent, being observed in 5-8\% of cases [34, 79, 81, 84]. Other extrapulmonary manifestations, such as arthralgia and ocular or gastrointestinal involvement, were observed in $\sim 10 \%$ of cases in some series [34, 79, 81, 84]. There have been anecdotal reports of involvement of numerous other organs [34, 79, 81, 84, 85], including muscle, thyroid, liver, spleen, testicle, bone marrow, adrenal glands, heart, prostate, ovaries, etc.

Diagnostic criteria. The diagnosis of LG is based on histological examination of surgical pulmonary samples. Endoscopic samples are rarely positive [34]. Other histological samples of adequate size can sometimes be obtained by biopsy of skin lesions (positive in $44 \%$ of cases) or ENT tissues (86\%) [34]. It is recommended to biopsy all accessible sites, owing to the variable proportions of atypical cells found at a given time in the different lesions.

Results of standard histological analysis. Macroscopically, these lesions are relatively well-defined nodules of variable size, grey, white or yellowish, and sometimes necrotic and cavitated. The infiltrate is polymorphous, being composed of lymphocytes (small or medium size, sometimes irregular, but with a mature-looking chromatin and nucleolus), associated with more immature activated lymphoid, plasmocytoid or immunoblastic cells and with large, more or less irregular, blastic cells [81-83, 86, 95]. Cell numbers are variable, and clumps of cells can occur. Mitotic activity is also variable (at least one mitosis per low-power field) according to LiEBow et al. [79]. Mitoses are usually found alongside zones of necrosis or around vessels [85]. Mature plasmocytes or macrophages are also present. There are no Sternberg cells. Polymorphonuclear neutrophils and eosinophils are generally absent [79, 82, 92]. Similarly, there is no epithelioid or gigantocellular granuloma tissue $[79,82]$.

The vascular tropism of this infiltrate affects vessels of all types (fig. 3), but particularly muscle veins and arterioles. The cellular infiltrate is mainly parietal, raising the endothelium and restricting the lumen [79, 87]. Endoluminal invasion and vessel thrombosis are rarer [79]. The angiocentrism is sometimes only visible after staining the slides for vascular elastin, especially when the vessel is masked by a dense cellular infiltrate. The adjacent pulmonary tissue can harbour organising alveolar lesions [79, 82]. The bronchioles are sometimes ulcerated or obliterated by granulation tissue $[79,82]$.

Contribution of immunohistochemistry. Immunohistochemistry helps to confirm the lymphoid nature of the lesion and its high cellularity (predominantly CD4+ $\mathrm{T}$ lymphocytes) [83, 91, 92, 96]. In particular, on paraffin sections suitable for morphological analysis, it shows that the atypical large cells are also lymphoid (CD45) and usually bear B-cell markers (fig. 3) [83, 86, 87, 91-94, 96]. CD30 antigen expression is sometimes found [107]. The search for clonality must focus on these cells, with the aim of demonstrating either an aberrant phenotype of the B-cell lineage (CD20+/CD43+) [87] or restricted Ig light-chain expression [86, 87, 92]. In a number of cases these cells also express EBV LMP protein [107].

Contribution of molecular biology. Molecular biology shows the lymphomatous nature of a number of these lesions by demonstrating clonality, especially in the case of B-cell proliferation $[86,87]$. In addition, coupled to immunohistochemical methods, it can show EBV infection of these cells.

Differential diagnosis. Clinically, the main difficulty is in diagnosing LG in patients with multiple excavated nodular opacities and subacute general and respiratory signs (table 2). An infectious cause must be ruled out in localised forms, by histochemical staining (Ziehl, Grocott, Gram). Some aetiologies are more difficult to identify, owing to radiological-clinical and/or histological features resembling those of LG. These aetiologies include Wegener's granulomatosis, necrotising sarcoidosis, and benign granulomatous and lymphocytic angiitis $[6,34,79,80,85,88,108]$. Other histological entities can also be discussed, owing to their clinical expression and the possibility of lymphoid

Table 2. - Principal aetiologies of multiple, possibly excavated nodular opacities

\section{Frequent causes}

Metastasis (ENT, uterine, testicular cancer,

choriocarcinoma $)^{\#}$

Septic metastases (endocarditis)

Tuberculosis

Postembolic pulmonary infarction ${ }^{\#}$

Less frequent causes

Wegener's granulomatosis ${ }^{\#}$

Sarcoidosis (possibly necrotising)

Rheumatoid arthritis

Benign granulomatous and lymphocytic angiitis ${ }^{\#}$

Lymphomatoid granulomatosis, lymphoma

Opportunistic bacterial pneumonia (nocardiosis, actinomycosis, etc. $)^{\#}$

Invasive or semi-invasive aspergillosis, other mycoses ${ }^{\#}$

Multiple hamartochondromas

Multiple hydatid cysts

Amyloidosis

Pneumoconiosis

ENT: ear, nose and throat. ${ }^{\#}$ : the most frequent tentative diagnoses (extra-pulmonary signs and radiological excavation) [46]. 
lesions. Given the therapeutic implications, it is essential to rule out Hodgkin's disease and highgrade angiotropic NHL before diagnosing LG.

Pretreatment extension work-up. The extension workup comprises a search for cutaneous and especially neurological involvement, by cerebral MRI. Owing to their relative frequency, renal and ENT lesions should also be sought. Finally, node and bone marrow involvement must be searched for, as it makes the diagnosis of LG/diffuse NHL highly probable [81].

No particular laboratory test is required for diagnosis or prognostication in this setting. Anaemia, a biological inflammatory syndrome, hyperleukocytosis or, on the contrary, leucopenia or lymphopenia are often present $[34,81,82,84,85,88]$. The immunological work-up shows only nonspecific abnormalities [85, 88]. Antinuclear antibodies and rheumatoid factor are very rarely positive [81, 82]. Hypogammaglobulinaemia or hypergammaglobulinaemia with circulating immune complexes have been described [34, 81, 82]. Cutaneous anergy to recall antigens or dinitrochlorobenze is observed in $>50 \%$ of cases $[84,88]$. Lymphocyte proliferation to antigens or mitogens is also subnormal.

Course, prognosis and treatment. Course and prognostic factors. Although the boundaries between "malignancy and benignity" and "monoclonality and polyclonality" remain poorly defined in LG, the prognosis is generally poor. The median survival time among patients with LG is 4 yrs [34]. Death ensues in $38-88 \%$ of cases $[34,79,81,82,84]$. The median of survival time of patients who die is 6.5-19 months [34, 81, 82, 84, 99]. Death is usually due to asphyxia or haemoptysis (44-89\% of cases) [34, 79, 81, 82, 84, 99], neurological complications ( $7-31 \%$ of cases) or infections $(23-38 \%$ of cases), which may or may not be treatment related [34, 82, $85,99]$. In a number of cases, death is associated with nodal or visceral lymphoma $(5-47 \%$ of cases) [34, $81,82,84,85]$ or carcinoma (11\%) [34]. Among survivors, the median survival time is 2-4 yrs $(\leqslant 10 \mathrm{yrs})$ in the series with the longest follow-up [34, 81, 82, 84, 99]. Survival is better among patients who enter complete remission, although late relapses occur in $\sim 10 \%$ of cases $[34,82]$.

Very few studies have identified predictors of survival. Factors of good prognosis appear to include advanced age, lack of symptoms and unilateral radiological lesions. Factors of poor prognosis include onset before age 25, neurological lesions and haepatosplenomegaly [81, 82]. Sex, race and cutaneous involvement do not appear to influence the vital prognosis. Leucopenia, persistent fever or anergy appear to be associated with progression to more aggressive forms of LG [84]. Histologically, the presence of large numbers of large atypical cells and a high degree of necrosis may be pejorative factors [81, 82]. However, the latter were not confirmed in a recent study, in which none of the histological classifications was predictive of survival among patients with LG [87]. Owing to the variety of treatments used to treat
LG, their impact on outcome is difficult to deduce from survival curves.

Principles of treatment. There is no consensus on treatment. It is usually based on steroid therapy, alone or combined with cyclophosphamide (CPM), and combination chemotherapy $[34,79,81,82,84$, 99]. FAuci et al. [84] obtained prolonged complete remissions in seven out of $13(54 \%)$ patients treated for $L G$ with the combination of CPM $\left(2 \mathrm{mg} \cdot \mathrm{kg}^{-1}\right.$. day $\left.^{-1}\right)$ and prednisone (PDN) $\left(1 \mathrm{mg} \cdot \mathrm{kg}^{-1} \cdot \mathrm{day}^{-1}\right.$, tapering doses) for an average of 37 and 28 months, respectively. Nevertheless, eight patients $(61 \%)$ died of $\mathrm{LG}$, including seven of associated high-grade NHL resistant to chemotherapy escalation. LIPFORD et al. [83] also obtained complete responses in nine $(50 \%)$ out of 18 patients treated with CPM and PDN for LG of histological grades I (5 out of 9$)$, II ( 2 out of 6 ) and III ( 2 out of 3 ). Nevertheless, nine of these 18 patients $(50 \%)$ subsequently died of high-grade NHL refractory to different chemotherapy regimens. In this series, five of the eight patients with grade III LG who were initially treated with intensive combination chemotherapy remained in complete remission after a mean follow-up of nearly 7 yrs (1-12 yrs). Other groups have reported similar results with intensive combination chemotherapy [34]. These data suggest: 1) equivalent efficacy of the CPM/PDN combination and more intensive chemotherapies; 2) poor prognosis of patients who do not enter remission; and 3 ) the need for clinical, cytological or genetic criteria to detect NHL or anticipate its onset.

Localised pulmonary forms have been successfully treated with surgery and/or radiotherapy [81, 85, 88]. Radiotherapy has also been used to treat more diffuse and/or extrathoracic forms (especially cerebral involvement) [23, 53, 82, 84]. Simple monitoring may also be appropriate, as spontaneous complete remissions have been observed [34, 81, 82].

\section{Conclusion}

A good deal of progress has been made in understanding the pathophysiology of primary pulmonary lymphoma. The role of Epstein-Barr virus, for example, is now well documented in some cases of high-grade B-cell lymphoma and lymphomatoid granulomatosis. Similarly, it is possible that an infectious agent plays a role in the emergence of pulmonary mucosa-associated lymphoid tissue lymphoma (analogous to Helicobacter pylori in the stomach). The diagnosis of these clonal lymphoid proliferations has also benefited from advances in immunohistochemistry and molecular biology. These techniques must now be more thoroughly assessed in this setting, especially on small endoscopic biopsy samples, so as to avoid unnecessary, purely diagnostic thoracotomy. Treatment of these rare tumours is poorly standardised and patient registers must be created to define the best therapeutic strategies. 


\section{References}

1. Isaacson PG, Norton AJ. Extranodal lymphomas. New York, Churchill Livingstone, 1994.

2. Freeman C, Berg JW, Cutler SJ. Occurrence and prognosis of extranodal lymphomas. Cancer 1972; 29: 252-260.

3. Newton R, Ferlay J, Beral V, Devesa SS. The epidemiology of non-Hodgkin's lymphoma: comparison of nodal and extra-nodal sites. Int J Cancer 1997; 72: 923-930.

4. Clagettot AT, Payne WS. The surgical treatment of pulmonary neoplasms. A 10 year experience. J Thoracic Cardiovasc Surg 1964; 48: 391-400.

5. L'Hoste RJ Jr, Filippa DA, Lieberman PH, Bretsky S. Primary pulmonary lymphomas. A clinicopathologic analysis of 36 cases. Cancer 1984; 54: 1397-1406.

6. Jaffe ES, Travis WD. Lymphomatoid granulomatosis and lymphoproliferative disorders of the lung. In: Lynch JP, De Remmee RA, ed. Immunologically mediated pulmonary diseases. Philadelphia, JB Lippincott Company, 1991; pp. 274-301.

7. Salztein S. Pulmonary malignant lymphomas and pseudolymphomas: classification, therapy, and prognosis. Cancer 1963; 16: 928-955.

8. Marchevsky A, Padilla M, Kaneko M, Kleinerman J. Localized lymphoid nodules of lung. A reappraisal of the lymphoma versus pseudolymphoma dilemma. Cancer 1983; 51: 2070-2077.

9. Kennedy JL, Nathwani BN, Burke JS, Hill LR, Rappaport H. Pulmonary lymphomas and other pulmonary lymphoid lesions. A clinicopathologic and immunologic study of 64 patients. Cancer 1985; 56: 539-552.

10. Koss MN, Hochholzer L, Nichols PW, Wehunt WD, Lazarus AA. Primary non-Hodgkin's lymphoma and pseudolymphoma of lung: a study of 161 patients. Hum Pathol 1983; 14: 1024-1038.

11. Addis BJ, Hyjek E, Isaacson PG. Primary pulmonary lymphoma: a re-appraisal of its histogenesis and its relationship to pseudolymphoma and lymphoid interstitial pneumonia. Histopathology 1988; 13: 1-17.

12. Fiche M, Caprons F, Berger F, et al. Primary pulmonary non-Hodgkin's lymphomas. Histopathology 1995; 26: 529-37.

13. Herbert A, Wright DH, Isaacson PG, Smith JL. Primary malignant lymphoma of the lung: histopathologic and immunologic evaluation of nine cases. Hum Pathol 1984; 15: 415-422.

14. Le Tourneau A, Audouin J, Garbe L, et al. Primary pulmonary malignant lymphoma, clinical and pathological findings, immunocytochemical and ultrastructural studies in 15 cases. Hematol Oncol 1983; 1: 49-60.

15. Li G, Hansmann ML, Zwingers $\mathrm{T}$, Lennert $\mathrm{K}$. Primary lymphomas of the lung: morphological, immunohistochemical and clinical features. Histopathology 1990; 16: 519-531.

16. Peterson H, Snider HL, Yam LT, Bowlds CF, Arnn EH, Li CY. Primary pulmonary lymphoma. A clinical and immunohistochemical study of six cases. Cancer 1985; 56: 805-813.

17. Nicholson AG, Wotherspoon AC, Diss TC, et al. Pulmonary B-cell non-Hodgkin's lymphomas. The value of immunohistochemistry and gene analysis in diagnosis. Histopathology 1995; 26: 395-403.

18. Harris NL, Jaffe ES, Stein $\mathrm{H}$, et al. A revised
European-American classification of lymphoid neoplasms: a proposal from the International Lymphoma Study Group. Blood 1994; 84: 1361-1392.

19. Harris NL, Jaffe ES, Diebold J, Flandrin G, MullerHermelink HK, Vardiman J. Lymphoma classification - from controversy to consensus: the R.E.A.L. and WHO Classification of lymphoid neoplasms. Ann Oncol 2000; 11: Suppl. 1, 3-10.

20. Campo E, Miquel R, Krenacs L, Sorbara L, Raffeld M, Jaffe ES. Primary nodal marginal zone lymphomas of splenic and MALT type. Am J Surg Pathol 1999; 23: 59-68.

21. Nathwani BN, Anderson JR, Armitage JO, et al. Marginal zone B-cell lymphoma: A clinical comparison of nodal and mucosa-associated lymphoid tissue types. Non-Hodgkin's Lymphoma Classification Project. J Clin Oncol 1999; 17: 2486-2492.

22. Remstein ED, James CD, Kurtin PJ. Incidence and subtype specificity of API2-MALT1 fusion translocations in extranodal, nodal, and splenic marginal zone lymphomas. Am J Pathol 2000; 156: 1183-1188.

23. Isaacson PG. Mucosa-associated lymphoid tissue lymphoma. Semin Hematol 1999; 36: 139-147.

24. Cordier JF, Chailleux E, Lauque D, et al. Primary pulmonary lymphomas. A clinical study of 70 cases in nonimmunocompromised patients. Chest 1993; 103: 201-208.

25. Lee DK, Im JG, Lee KS, et al. B-cell lymphoma of bronchus-associated lymphoid tissue (BALT): CT features in 10 patients. $J$ Comput Assist Tomogr 2000; 24: 30-34.

26. Wislez M, Cadranel J, Antoine M, et al. Lymphoma of pulmonary mucosa-associated lymphoid tissue: CT scan findings and pathological correlations. Eur Respir $J$ 1999; 14: 423-429.

27. Drent M, Wagenaar SS, Mulder PH, van Velzen-Blad H, Diamant M, van den Bosch JM. Bronchoalveolar lavage fluid profiles in sarcoidosis, tuberculosis, and non-Hodgkin's and Hodgkin's disease. An evaluation of differences. Chest 1994; 105: 514-519.

28. Betsuyaku T, Munakata M, Yamaguchi E, et al. Establishing diagnosis of pulmonary malignant lymphoma by gene rearrangement analysis of lymphocytes in bronchoalveolar lavage fluid. Am J Respir Crit Care Med 1994; 149: 526-529.

29. Costabel U, Bross KJ, Matthys H. Diagnosis by bronchoalveolar lavage of cause of pulmonary infiltrates in haematological malignancies. $\mathrm{Br}$ Med J (Clin Res Ed) 1985; 290: 1041.

30. Davis WB, Gadek JE. Detection of pulmonary lymphoma by bronchoalveolar lavage. Chest 1987; 91: 787-790.

31. Keicho N, Oka T, Takeuchi K, Yamane A, Yazaki Y, Yotsumoto H. Detection of lymphomatous involvement of the lung by bronchoalveolar lavage. Application of immunophenotypic and gene rearrangement analysis. Chest 1994; 105: 458-462.

32. Kobayashi H, Ii K, Hizawa K, Maeda T. Two cases of pulmonary Waldenstrom's macroglobulinemia. Chest 1985; 88: 297-299.

33. Oka M, Kawano K, Kanda T, Hara K. Bronchoalveolar lavage in primary pulmonary lymphoma with monoclonal gammopathy. Am Rev Respir Dis 1988; 137: 957-959.

34. Pisani RJ, DeRemee RA. Clinical implications of the histopathologic diagnosis of pulmonary 
lymphomatoid granulomatosis. Mayo Clin Proc 1990; 65: 151-163.

35. Schwaiger A, Prior C, Weyrer $\mathrm{K}$, et al. NonHodgkin's lymphoma of the lung diagnosed by gene rearrangement from bronchoalveolar lavage fluid: a fast and noninvasive method. Blood 1991; 77: 2538 2539.

36. Shiota T, Chiba W, Ikeda S, Ikei N. Gene analysis of pulmonary pseudolymphoma. Chest 1993; 103: 335 338.

37. Subramanian D, Albrecht S, Gonzalez JM, Cagle PT Primary pulmonary lymphoma. Diagnosis by immunoglobulin gene rearrangement study using a novel polymerase chain reaction technique. Am Rev Respir Dis 1993; 148: 222-226.

38. Weynants P, Cordier JF, Cellier CC, Pages J, Loire R, Brune J. Primary immunocytoma of the lung: the diagnostic value of bronchoalveolar lavage. Thorax 1985; 40: 542-543.

39. Pisani RJ, Witzig TE, Li CY, Morris MA, Thibodeau SN. Confirmation of lymphomatous pulmonary involvement by immunophenotypic and gene rearrangement analysis of bronchoalveolar lavage fluid. Mayo Clin Proc 1990; 65: 651-656.

40. Philippe B, Delfau-Larue MH, Epardeau B, et al. B-cell pulmonary lymphoma: gene rearrangement analysis of bronchoalveolar lymphocytes by polymerase chain reaction. Chest 1999; 115: 1242-1247.

41. Cordier JF, Cellier CC, Vincent M, Loire R, Creyssel $\mathrm{R}$, Brune J. Monoclonal gammopathies in chest disease. Thorax 1985; 40: 629-630.

42. Isaacson PG. B cell lymphomas of mucosa associated lymphoid tissue (MALT). Bull Cancer 1991; 78: 203 205.

43. Turner RR, Colby TV, Doggett RS. Well-differentiated lymphocytic lymphoma. A study of 47 patients with primary manifestation in the lung. Cancer 1984; 54: 2088-2096.

44. Harris NL, Isaacson PG. What are the criteria for distinguishing MALT from non-MALT lymphoma at extranodal sites? Am J Clin Pathol 1999; 111: S126S132.

45. Dorfman DM, Pinkus GS. Utility of immunophenotypic studies in the diagnosis of low-grade lymphoma of mucosa-associated lymphoid tissue (MALT) and other low-grade non Hodgkin's lymphomas of extranodal sites. Appl Immunohistochem 1995; 3: 160-167.

46. Grenier P. Syndromes radiologiques. In: Flammarion, ed. Medicine-Sciences Imagerie thoracique de 1'adulte. Paris, 1998

47. Yousem SA, Colby TV. Pulmonary lymphomas and lymphoid hyperplasias. In: Knowles DM, ed. Neoplastic Hematopathology. Baltimore, Williams and Wilkins, 1991; pp. 979-1007.

48. Dail DH, Hammar SP. Pulmonary Pathology. New York, Springer-Verlag, 1994.

49. Zinzani PL, Magagnoli M, Galieni $\mathrm{P}$, et al. Nongastrointestinal low-grade mucosa-associated lymphoid tissue lymphoma: analysis of 75 patients. J Clin Oncol 1999; 17: 1254

50. Thieblemont C, Berger F, Dumontet C, et al. Mucosaassociated lymphoid tissue lymphoma is a disseminated disease in one third of 158 patients analyzed. Blood 2000; 95: 802-806.

51. Raderer M, Vorbeck F, Formanek $\mathrm{M}$, et al. Importance of extensive staging in patients with mucosa-associated lymphoid tissue (MALT)-type lymphoma. Br J Cancer 2000; 83: 454 457.

52. Kurtin PJ, Myers JL, Adlakha $\mathrm{H}$, et al. Pathologic and clinical features of primary pulmonary extranodal marginal zone B-cell lymphoma of MALT type. Am J Surg Pathol 2001; 25: 997-1008.

53. Thieblemont C, Bastion Y, Berger F, et al. Mucosaassociated lymphoid tissue gastrointestinal and nongastrointestinal lymphoma behavior: analysis of 108 patients. J Clin Oncol 1997; 15: 1624-1630.

54. Ferraro P, Trastek VF, Adlakha H, Deschamps C, Allen MS, Pairolero PC. Primary non-Hodgkin's lymphoma of the lung. Ann Thorac Surg 2000; 69: 993-997.

55. Morgner A, Miehlke S, Fischbach W, et al. Complete remission of primary high-grade B-cell gastric lymphoma after cure of Helicobacter pylori infection. J Clin Oncol 2001; 19: 2041-2048.

56. Frizzera G, Hanto DW, Gajl-Peczalska KJ, et al. Polymorphic diffuse B-cell hyperplasias and lymphomas in renal transplant recipients. Cancer Res 1981; 41: 4262-4279.

57. Nalesnik MA, Jaffe R, Starzl TE, et al. The pathology of posttransplant lymphoproliferative disorders occurring in the setting of cyclosporine A-prednisone immunosuppression. Am J Pathol 1988; 133: 173-192.

58. Starzl TE, Nalesnik MA, Porter KA, et al. Reversibility of lymphomas and lymphoproliferative lesions developing under cyclosporin-steroid therapy. Lancet 1984; 1: 583-587.

59. Yousem SA, Randhawa P, Locker J, et al. Posttransplant lymphoproliferative disorders in heart-lung transplant recipients: primary presentation in the allograft. Hum Pathol 1989; 20: 361-369.

60. Cadranel J, Naccache J, Wislez M, Mayaud C. Pulmonary malignancies in the immunocompromised patient. Respiration 1999; 66: 289-309.

61. Polish LB, Cohn DL, Ryder JW, Myers AM, O'Brien RF. Pulmonary non-Hodgkin's lymphoma in AIDS. Chest 1989; 96: 1321-1326.

62. Raphael M, Gentilhomme O, Tulliez M, Byron PA, Diebold J. Histopathologic features of high-grade nonHodgkin's lymphomas in acquired immunodeficiency syndrome. The French Study Group of Pathology for Human Immunodeficiency Virus-Associated Tumors. Arch Pathol Lab Med 1991; 115: 15-20.

63. Ray P, Antoine M, Mary-Krause M, et al. AIDSrelated primary pulmonary lymphoma. Am J Respir Crit Care Med 1998; 158: 1221-1229.

64. Strimlan CV, Taswell HF, Kueppers F, DeRemee RA, McDonald TJ. HLA-A antigens of patients with Wegener's granulomatosis. Tissue Antigens 1978; 11: $129-131$.

65. Lacoste V, Judde JG, Bestett G, et al. Virological and molecular characterisation of a new B lymphoid cell line, established from an AIDS patient with primary effusion lymphoma, harbouring both KSHV/HHV8 and EBV viruses. Leuk Lymphoma 2000; 38: 401-409.

66. Iuchi K, Ichimiya A, Akashi A, et al. Non-Hodgkin's lymphoma of the pleural cavity developing from longstanding pyothorax. Cancer 1987; 60: 1771-1775.

67. Chadburn A, Cesarman E, Jagirdar J, Subar M, Mir RN, Knowles DM. CD30 (Ki-1) positive anaplastic large cell lymphomas in individuals infected with the human immunodeficiency virus. Cancer 1993; 72: 3078-3090.

68. Martin A, Capron F, Liguory-Brunaud MD, 
De Frejacques C, Pluot M, Diebold J. Epstein-Barr virus-associated primary malignant lymphomas of the pleural cavity occurring in longstanding pleural chronic inflammation. Hum Pathol 1994; 25: 1314 1318.

69. Bazot M, Cadranel J, Benayoun S, Tassart M, Bigot JM, Carette MF. Primary pulmonary AIDS-related lymphoma: radiographic and CT findings. Chest 1999; 116: 1282-1286.

70. Joseph G, Pandit M, Korfhage L. Primary pulmonary plasmacytoma. Cancer 1993; 71: 721-724.

71. Koss MN, Moran CA, Frizzera G. Pulmonary lasmocytomas: aclinicopathologic and immunohistochemical study of five cases. Ann Diagn Pathol 1998; 2: $1-11$.

72. Horiuchi T, Hirokawa M, Oyama Y, et al. Diffuse pulmonary infiltrates as a roentgenographic manifestation of primary pulmonary plasmacytoma. Am J Med 1998; 105: 72-74.

73. Morinaga S, Watanabe H, Gemma A, et al. Plasmacytoma of the lung associated with nodular deposits of immunoglobulin. Am J Surg Pathol 1987; 11: 989995.

74. Stroup RM, Moncada A, Purdy LJ, Battifora H. Angiotropic (intravascular) large cell lymphoma. A clinicopathologic study of seven cases with unique clinical presentations. Cancer 1990; 66: 1781-1788.

75. Snyder LS, Harmon KR, Estensen RD. Intravascular lymphomatosis (malignant angioendotheliomatosis) presenting as pulmonary hypertension. Chest 1989; 96: 1199-2000.

76. Yousem SA, Colby TV. Intravascular lymphomatosis presenting in the lung. Cancer 1990; 65: 349-353.

77. Walls JG, Hong YG, Cox JE, et al. Pulmonary intravascular lymphomatosis: presentation with dyspnea and air trapping. Chest 1999; 115: 1207-1210.

78. Demirer T, Dail DH, Aboulafia DM. Four varied cases of intravascular lymphomatosis and a literature review. Cancer 1994; 73: 1738-1745.

79. Liebow AA, Carrington CR, Friedman PJ. Lymphomatoid granulomatosis. Hum Pathol 1972; 3: 457-558.

80. Liebow AA. The J. Burns Amberson lecture pulmonary angiitis and granulomatosis. Am Rev Respir Dis 1973; 108: 1-18.

81. Katzenstein AL, Liebow AA. Lymphomatoid granulomatosis. A clinicopathologic study of 152 cases. Cancer 1979; 43: 360-373.

82. Koss MN, Hochholzer L, Langloss JM, Wehunt WD, Lazarus AA, Nichols PW. Lymphomatoid granulomatosis: a clinicopathologic study of 42 patients. Pathology 1986; 18: 283-288.

83. Lipford EH Jr, Margolick JB, Longo DL, Fauci AS, Jaffe ES. Angiocentric immunoproliferative lesions: a clinicopathologic spectrum of post-thymic T-cell proliferations. Blood 1988; 72: 1674-1681.

84. Fauci AS, Harley JB, Roberts WC, Ferrans VJ, Gralnick HR, Bjornson BH. NIH conference. The idiopathic hypereosinophilic syndrome. Clinical, pathophysiologic, and therapeutic considerations. Ann Intern Med 1982; 97: 78-92.

85. Saldana MJ, Patchefsky AS, Israel HI, Atkinson GW. Pulmonary angiitis and granulomatosis. The relationship between histological features, organ involvement, and response to treatment. Hum Pathol 1977; 8: 391409.

86. Guinee JE, Kigma D. Pulmonary lymphomatoid granulomatosis. Evidence for a proliferation of
Epstein-Bar virus infected B-lymphocytes with proeminent T-cell component and vasculitis. Am J Surg Pathol 1994; 18: 753-764.

87. Myers JL, Kurtin PJ, Katzenstein AL, et al. Lymphomatoid granulomatosis. Evidence of immunophenotypic diversity and relationship to Epstein-Barr virus infection. Am J Surg Pathol 1995; 19: 1300-1312.

88. Israel HL, Patchefsky AS, Saldana MJ. Wegener's granulomatosis, lymphomatoid granulomatosis, and benign lymphocytic angiitis and granulomatosis of lung. Recognition and treatment. Ann Intern Med 1977; 87: 691-699.

89. Jaffe ES. Pathologic and clinical spectrum of postthymic T-cell malignancies. Cancer Invest 1984; 2: $413-426$.

90. Guinee DG Jr, Perkins SL, Travis WD, Holden JA, Tripp SR, Koss MN. Proliferation and cellular phenotype in lymphomatoid granulomatosis: implications of a higher proliferation index in B cells. Am J Surg Pathol 1998; 22: 1093-1100.

91. Gaulard P, Henni T, Marolleau JP, et al. Lethal midline granuloma (polymorphic reticulosis) and lymphomatoid granulomatosis. Evidence for a monoclonal T-cell lymphoproliferative disorder. Cancer 1988; 62: 705-710.

92. Medeiros LJ, Peiper SC, Elwood L, Yano T, Raffeld M, Jaffe ES. Angiocentric immunoproliferative lesions: a molecular analysis of eight cases. Hum Pathol 1991; 22: 1150-1157.

93. Weis JW, Winter MW, Phyliky RL, Banks PM. Peripheral T-cell lymphomas: histologic, immunohistologic, and clinical characterization. Mayo Clin Proc 1986; 61: 411-426.

94. Whittaker S, Foroni L, Luzzatto L, et al. Lymphomatoid granulomatosis - evidence of a clonal T-cell origin and an association with lethal midline granuloma. Q J Med 1988; 68: 645-655.

95. DeRemee RA, Weiland LH, McDonald TJ. Polymorphic reticulosis, lymphomatoid granulomatosis. Two diseases or one? Mayo Clin Proc 1978; 53: 634 640.

96. Donner LR, Dobin S, Harrington D, Bassion S, Rappaport ES, Peterson RF. Angiocentric immunoproliferative lesion (lymphomatoid granulomatosis). A cytogenetic, immunophenotypic, and genotypic study. Cancer 1990; 65: 249-254.

97. Katzenstein AL, Peiper SC. Detection of Epstein-Barr virus genomes in lymphomatoid granulomatosis: analysis of 29 cases by the polymerase chain reaction technique. Mod Pathol 1990; 3: 435-441.

98. Taniere P, Thivolet-Bejui F, Vitrey D, et al. Lymphomatoid granulomatosis - a report on four cases: evidence for B phenotype of the tumoral cells. Eur Respir J 1998; 12: 102-106.

99. Colby TV, Carrington CB. Pulmonary lymphomas simulating lymphomatoid granulomatosis. Am J Surg Pathol 1982; 6: 19-32.

100. Patton WF, Lynch JP III. Lymphomatoid granulomatosis. Clinicopathologic study of four cases and literature review. Medicine (Baltimore) 1982; 61:1-12.

101. Lee SC, Roth LM, Brashear RE. Lymphomatoid granulomatosis: A clinicopathologic study of four cases. Cancer 1976; 38: 846-853.

102. Wechsler RJ, Steiner RM, Israel HL, Patchefsky AS. Chest radiograph in lymphomatoid granulomatosis: comparison with Wegener granulomatosis. AJR Am J Roentgenol 1984; 142: 79-83. 
103. Rabinowitz JG, Cohen BA, Mendelson DS. Lymphomatoid granulomatosis. Jama 1985; 254: 3458 3460.

104. Dee PM, Arora NS, Innes DJ Jr. The pulmonary manifestations of lymphomatoid granulomatosis. Radiology 1982; 143: 613-618.

105. Lee JS, Tuder R, Lynch DA. Lymphomatoid granulomatosis: radiologic features and pathologic correlations. AJR Am J Roentgenol 2000; 175: 1335-1339.

106. Frazier AA, Rosado-de-Christenson ML, Galvin JR,
Fleming MV. Pulmonary angiitis and granulomatosis: radiologic-pathologic correlation. Radiographics 1998; 18: 687-710. quiz 727.

107. Sabourin JC, Kanavaros P, Briere J, et al. EpsteinBarr virus (EBV) genomes and EBV-encoded latent membrane protein (LMP) in pulmonary lymphomas occurring in nonimmunocompromised patients. Am J Surg Pathol 1993; 17: 995-1002.

108. Gracey DR. Tuberculosis in the world today. Mayo Clin Proc 1988; 63: 1251-1255. 